\title{
CRYSTALLIZATION AND MECHANICAL PROPERTIES OF (45S5-HA) BIOCOMPOSITE FOR BIOMEDICAL IMPLANTATION
}

\author{
"SUNIL PRASAD, VIKAS KUMAR VYAS, MD. ERSHAD, RAM PYARE \\ Department of Ceramic Engineering, Indian Institute of Technology (BHU), \\ Varanasi-221005, India \\ "E-mail: sunilmnnit25@gmail.com
}

Submitted April 12, 2017; accepted June 2, 2017

\begin{abstract}
Keywords: Bioglass, Hydroxyapatite (HA), Biocomposites, SBF
Bioglass $^{\circledR}$ (45S5) was prepared by conventional melting process and hydroxyapatite (HA) was prepared by sol-gel method. The bioglass (45S5) and hydroxyapatite $\left(\mathrm{Ca}_{10}\left(\mathrm{PO}_{4}\right)_{6}(\mathrm{OH})_{2}\right)$ samples were mixed in a particular proportion to prepare composite by using hydraulic pressing. Based on thermogravimetric and differential thermal analysis, the composite were sintered with a suitable heat treatment process at $1000-1050^{\circ} \mathrm{C}$. The in-vitro bioactivity of samples was determined in simulated body fluid for 1, 3, 7, 14 and 21 days. The bioactivity was examined in vitro with respect to the ability of hydroxyapatite layer formation on the surface of samples when they were immersed in simulated body fluid (SBF). DTA/TGA, XRD, SEM and mechanical studies were conducted for different characteristic measurement of biocomposites. The result shows the enhancement in bioactivity and mechanical properties of (45S5-HA) biocomposites for clinical implantation.
\end{abstract}

\section{INTRODUCTION}

The $45 \mathrm{~S} 5^{\circledR}$ bioactive glass has very good capability to bond with both soft and hard tissue. Bioactive material should possess good biochemical behaviour and biomechanical strength [1]. Hydroxyapatite $\left(\mathrm{Ca}_{10}\left(\mathrm{PO}_{4}\right)_{6}(\mathrm{OH})_{2}, \mathrm{HA}\right)$ and bioglass $(\mathrm{BG})$ bio-compatible ceramic materials has the capacity to promote favorable bone-tissue formation and commonly used as replacing material in orthopedics, dentistry, maxillofacial surgery and tissue engineering [2]. Bioactive glass 45S5 granules include five substances $46.1 \mathrm{~mol}$. \% $\mathrm{SiO}_{2}$, 26.9 mol. $\% \mathrm{CaO}, 24.4$ mol. $\% \mathrm{Na}_{2} \mathrm{O}$ and 2.6 mol. $\% \mathrm{P}_{2} \mathrm{O}_{5}$ as compared to other types of bioactive glass. It has some advantages such as appropriate percentage of silicon, a proper $\mathrm{Ca} / \mathrm{P}$ ratio, remarkable biological performance, and an active surface. It offers promising potential for repairing the bone defects [3]. Amorphous bioactive glass is suitable to fill bone defects but can also be used as coating material for implants in direct bone contact to enhance the process of ossification [4-7].

Hydroxyapatite is the most extensively researching material used in periodontal defects. Synthetic HA is a biocompatible, non-toxic, slowly resorbing, osteoconductive, osteophillic material and has close structural and chemical properties like bone mineral but not identical. Bioactive glass can form a chemical bond with living hard tissues through the development of a surface layer of carbonated hydroxyapatite [8]. Bioactive glass, particularly 45S5 $[9,10]$ has been widely used in clinical practices because of its excellent biocompatibility, osteogenic capability, and osteointegrative properties. It is reported that $\mathrm{BG}$ guides and promotes osteogenesis and allows rapid bone formation. Due to uncontrolled kinetics of the chemical reactions in the sol-gel process, it is difficult to incorporate additives without destroying the amorphous glassy network [11-12]. The prepared bioglass $45 \mathrm{~S} 5^{\circledR}$ by the sol-gel route have invariably resulted in gel powders containing crystalline inclusions or bioglass-ceramics. Recently, a sol-gel procedure which overcomes these challenges by obtaining a completely amorphous glass with composition similar to bioglass 45S5 has been demonstrated [13]. Partial listing of these properties are uniform porosity with macro as well as micro-sized pores, non-toxicity to the host tissue, biodegradation and bioresorption with sufficient mechanical properties [14].

The degradable glass $\mathrm{Na}_{2} \mathrm{O}-\mathrm{CaO}-\mathrm{SiO}_{2}-\mathrm{P}_{2} \mathrm{O}_{5}$ system was rich in $\mathrm{CaO}$ content and its composition is similar to a ternary $\mathrm{Na}_{2} \mathrm{O}-\mathrm{CaO}-\mathrm{SiO}_{2}$ system $[15,16]$. The osteogenic properties of the glass were considered to be due to the dissolution products of the glass [17]. However, its relatively low strength and brittleness limits its application to non-load bearing conditions [18]. The apatite can be formed biomimetically on bioactive materials even in simulated body fluid with ion concentrations. $\mathrm{TiO}_{2}$ has a tendency to adsorb water on the surface, resulting in the formation of titanium hydroxide groups. The basic $\mathrm{Ti}-\mathrm{OH}$ groups were reported to induce apatite nucleation and crystallization in SBF [19]. 


\section{EXPERIMENTAL}

Preparation of biocomposites

By melting route, bioglass powder is mixed with HA powder (sol-gel) 5, 10, 15, 20 (wt. \%) compacted at $1500 \mathrm{MPa}$ pressure into cylindrical samples $(1 \mathrm{~cm}, 1 \mathrm{~cm})$ and sintered at $1000-1050^{\circ} \mathrm{C}$ to prepare the composites as shown in Table 1.

Table 1. Composition of bioactive glass and bio-composite (BC1, BC2, BC3, BC4).

\begin{tabular}{|c|c|c|c|c|}
\hline \multirow[b]{2}{*}{ BG (45S5) } & \multicolumn{4}{|c|}{ Composition (wt. \%) } \\
\hline & $45 \mathrm{SiO}_{2}$ & $24.5 \mathrm{Na}_{2} \mathrm{O}$ & $24.5 \mathrm{CaO}$ & $6 \mathrm{P}_{2} \mathrm{O}_{5}$ \\
\hline $\begin{array}{l}\text { Biocomposite } \\
\text { samples }\end{array}$ & \multicolumn{2}{|c|}{$\mathrm{BG}(45 \mathrm{~S} 5)$} & \multicolumn{2}{|c|}{ HA } \\
\hline$\overline{\mathrm{BC} 1}$ & \multicolumn{2}{|c|}{95} & 5 & \\
\hline $\mathrm{BC} 2$ & \multicolumn{2}{|c|}{90} & 10 & \\
\hline $\mathrm{BC} 3$ & \multicolumn{2}{|c|}{85} & 15 & \\
\hline $\mathrm{BC} 4$ & \multicolumn{2}{|c|}{80} & 20 & \\
\hline
\end{tabular}

Table 2. Ion concentration (mM/litre) of simulated body fluid and human blood plasma.

\begin{tabular}{llrr}
\hline & Ion & Simulated body fluid & Blood plasma \\
\hline 1. & $\mathrm{Na}^{+}$ & 142.0 & 142.0 \\
2. & $\mathrm{K}^{+}$ & 5.0 & 5.0 \\
3. & $\mathrm{Ca}^{2+}$ & 2.5 & 2.5 \\
4. & $\mathrm{Mg}^{2+}$ & 1.5 & 1.5 \\
5. & $\mathrm{HCO}_{3}^{-}$ & 4.2 & 27.0 \\
6. & $\mathrm{Cl}^{-}$ & 148.0 & 103.0 \\
7. & $\mathrm{HPO}_{4}{ }^{2-}$ & 1.0 & 1.0 \\
8. & $\mathrm{SO}_{4}{ }^{2-}$ & 0.5 & 0.5 \\
\hline
\end{tabular}

\section{Preparation of SBF}

In order to identify the HCA layer formation, the biocomposite samples were immersed in SBF solution at $37.4^{\circ} \mathrm{C}$ for different time periods from 1 to 21 days. The SBF solution was prepared according to the formula explained by Kokubo et al. [20]. Table 2 shows the reagents for the preparation of $\mathrm{SBF}$, comparison of ionic concentrations in SBF and human blood plasma. The $\mathrm{pH}$ of the SBF solution was measured by using a digital $\mathrm{pH}$ meter after immersion of samples for different time periods.

\section{DTA/TGA analysis}

Hydroxyapatite reinforced glass biocomposite were subjected to differential thermal analysis (DTA) to determine the composite nucleation and crystallization temperatures. The prepared biocomposite were powdered by using an agate mortar and pestle and subjected for differential thermal analyzer (SETARAM, France) at a heating rate of $10^{\circ} \mathrm{C} \cdot \mathrm{min}^{-1}$ under a stream of oxygen atmosphere against reference material of alumina. The DTA test was carried out from room temperature to $1000^{\circ} \mathrm{C}$. The prepared bioactive glass samples were heat treated in two-steps, firstly glass transition temperature for the formation of nuclei sites and after holding for the specific time, It was further heated to second selected crystal growth temperature for growth.

Powder X-ray diffraction

(XRD) measurements

The biocomposite samples were ground to $75 \mathrm{mic}-$ rons and the fine powders were subjected to X-ray diffraction analysis (XRD) using RIGAKU-Miniflex II diffractometer adopted $\mathrm{Cu}-\mathrm{K} \alpha$ radiation $\left(\lambda=1.5405 \mathrm{~A}^{\circ}\right)$ with a tube voltage of $40 \mathrm{kV}$ and current of $35 \mathrm{~mA}$ in a $2 \theta$ range between $20^{\circ}$ to $80^{\circ}$. The step size and measuring speed was set to $0.02^{\circ}$ and $1^{\circ}$ per min respectively. The JCPDS-International Centre for Diffraction Data Cards were used as a reference.

Scanning electron microscope (SEM)

Scanning electron microscopy (Inspect50FEI) was used to analyse the surfaces of biocomposite before and after immersion in SBF solution. Before SEM analysis, the samples were coated with plasma gold plate.

\section{$\mathrm{pH}$ measurement}

For measuring $\mathrm{pH}$ by using microprocessor based pH-EC meter (model-1611,ESICO-USA), 2 gm biocomposite powder were soaked in a small plastic container of $20 \mathrm{ml}$ of SBF solution at $37^{\circ} \mathrm{C}$ with $\mathrm{pH} 7.40$ for $1,3,7$, 14 and 21 days time period.

\section{Density and mechanical properties measurements}

The density of biocomposite samples was determined by Archimedes principle, using distilled water as buoyant. All the weight measurements have been made using a digital balance (Sartorius,Model: BP221S, USA) having an accuracy of $\pm 0.0001 \mathrm{gm}$. Density $(\rho)$ of sample was obtained by employing the relation (1) as given below:

$$
\rho=\frac{W a}{W a-W b} \rho b
$$

where $W_{a}$ is the weight of sample in air, $W_{b}$ is the weight of sample in buoyant and $\rho b$ is the density of buoyant. 


\section{RESULTS AND DISCUSSION}

Differential thermal analysis

(DTA/TGA) of biocomposite

The differential thermal analysis (DTA/TGA) curve of biocomposite shown in Figure 1. Due to incorporation of hydroxyapatite in base bioactive glass, there is increase in biocomposite endothermic as well as exothermic peaks. This increase in temperature is due to hydroxyapatite acting as a modifier which strengthen the $(\mathrm{Si}-\mathrm{O}-\mathrm{Si})$ silica network. The results demonstrated $\mathrm{Tg}$ temperature was from $489^{\circ} \mathrm{C}$ to $554^{\circ} \mathrm{C}$ and $\mathrm{Tc}$ from $1005^{\circ} \mathrm{C}$ to $1093^{\circ} \mathrm{C}[21]$.

\section{Phase analysis}

$\mathrm{XRD}$ was used to characterize the prepared samples of biocomposite as $\mathrm{BC} 1, \mathrm{BC} 2, \mathrm{BC} 3$ and $\mathrm{BC} 4$ (all of the samples in Table 1). XRD patterns of these samples show that the main phases are pseudo wollastonite and hydroxyapatite (JCPDS No.: 090432). The conclusion shows that the synthesized bioglass has been partly crystallized at $1000^{\circ} \mathrm{C}$. This has been reported that pseudo wollastonite is a bioactive material, and its invitro tests have been investigated [22-26].

In order to compare the intensity of the formed phases results can be seen in Figure 2. Two characteristic peaks of pseudo wollastonite (JCPDS No.: 19-0248)

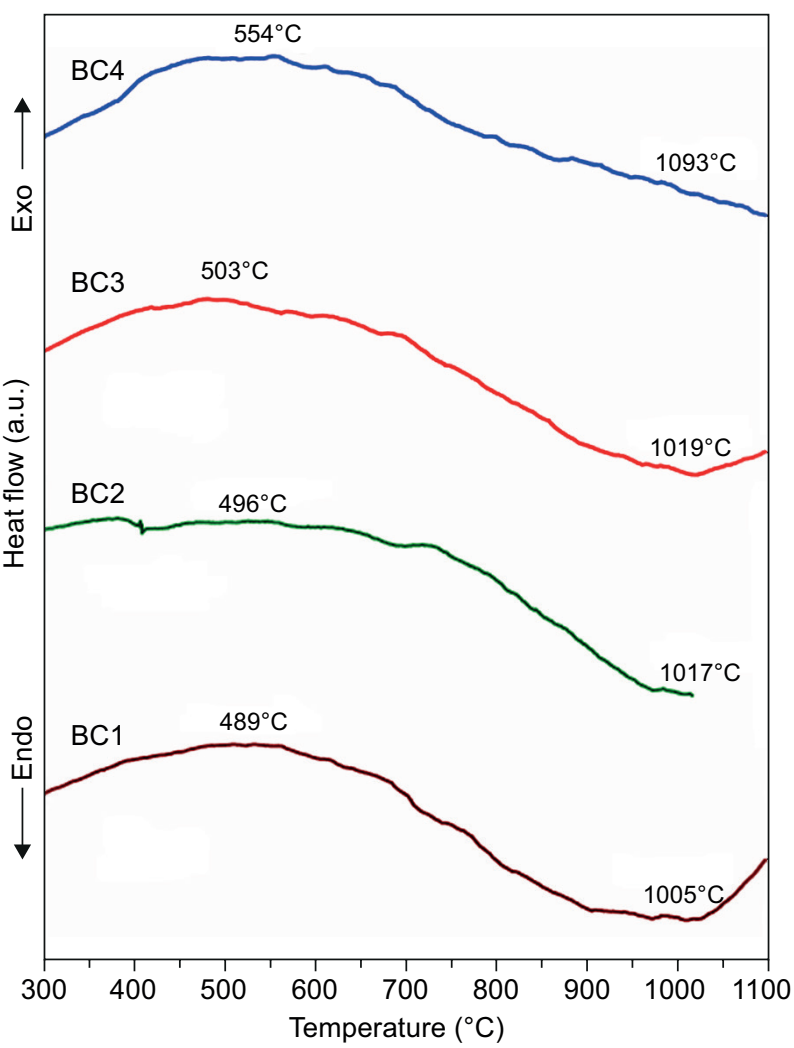

Figure 1. DTA/TGA analysis of biocomposites (BC1, BC2, BC3, BC4) samples. and hydroxyapatite were selected for comparison. $2 \theta=$ $=36.80^{\circ}$ for Wollastonite and $2 \theta=40.17^{\circ}$ for hydroxyapatite phase were selected and their intensities were compared. The silicon and sodium oxides could react with hydroxyapatite phase in biocomposite and as result the $\mathrm{OH}$ ions would be eliminated from the structure as water vapor. This reaction will be cause the formation of sodium calcium silicates $\left(\mathrm{Na}_{2} \mathrm{CaSi}_{2} \mathrm{O}_{6}\right)$ which was sintered at $1000^{\circ} \mathrm{C}$ mainly shows the presence of sodium calcium silicates $\left(\mathrm{Na}_{2} \mathrm{CaSi}_{2} \mathrm{O}_{6}\right.$, JCPDS \# 77-2189). This indicates that sintering promotes the transformation of hydroxyapatite to $\beta$-TCP [27].

$$
\begin{aligned}
& 2 \mathrm{Ca}_{5}\left(\mathrm{PO}_{4}\right)_{3} \mathrm{OH}+\mathrm{Na}_{2} \mathrm{O}+2 \mathrm{SiO}_{2} \rightarrow \\
& \rightarrow \mathrm{Na}_{2} \mathrm{CaSi}_{2} \mathrm{O}_{6}+3 \mathrm{Ca}_{3}\left(\mathrm{PO}_{4}\right)_{2}+\mathrm{H}_{2} \mathrm{O}
\end{aligned}
$$

It has been found that sample $\mathrm{BC} 4$ has the most content of hydroxyapatite (silicated hydroxyapatite in fact as described later) and sample $\mathrm{BC} 1$ has the least content of hydroxyapatite thus it can be said that it has the most content of wollastonite.

\section{SEM analysis of biocomposite samples}

Surface morphology of biocomposite samples before and after post-immersion in SBF, the glass releases $\mathrm{Ca}^{2+}$ and $\mathrm{Na}^{+}$ions from its surface via an ex-change with the $\mathrm{H}_{3} \mathrm{O}^{+}$ion in the $\mathrm{SBF}$ to form $\mathrm{Si}-\mathrm{OH}$ groups

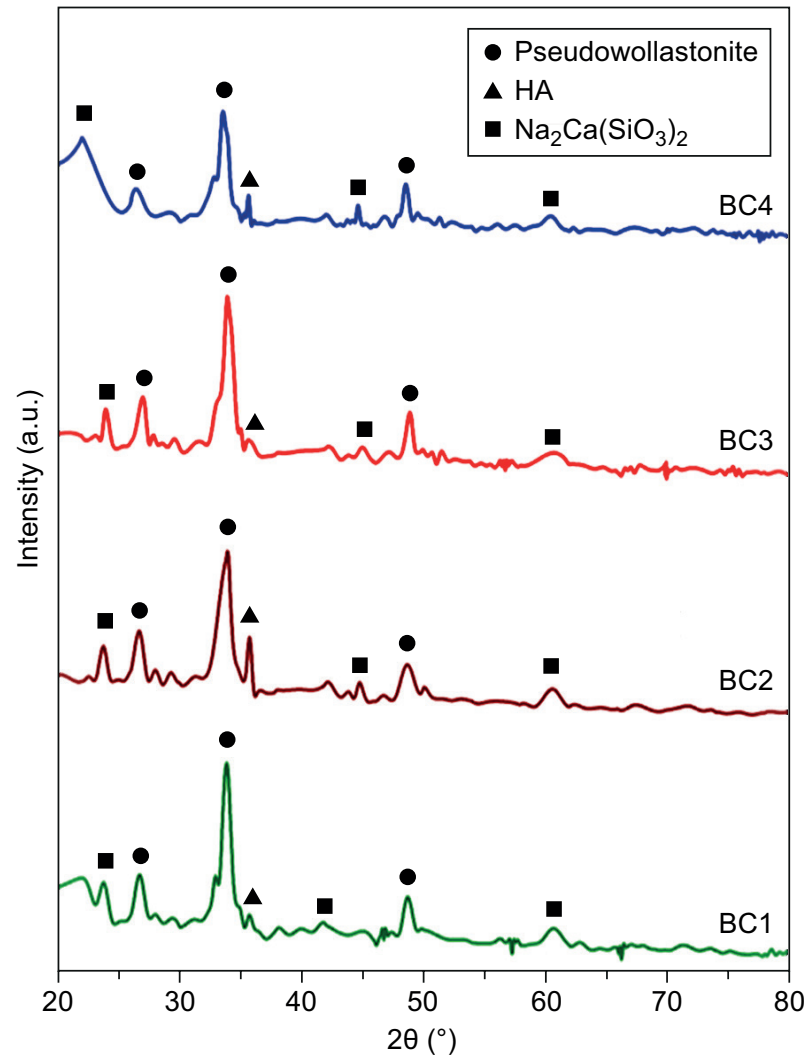

Figure 2. X-ray diffraction of the prepared $(\mathrm{BC} 1, \mathrm{BC} 2, \mathrm{BC}$, BC4) composites. 
on their surfaces [28]. Water molecules in the SBF simultaneously reacts with the $\mathrm{Si}-\mathrm{O}-\mathrm{Si}$ bond to form additional $\mathrm{Si}-\mathrm{OH}$ groups, the formed $\mathrm{Si}-\mathrm{OH}$ groups induce apatite nucleation and the released $\mathrm{Ca}^{2+}$ and $\mathrm{Na}^{+}$ ions accelerate apatite nucleation by increasing the ionic activity product of apatite in the fluid [29]. As a result after soaking in SBF in a 21 days period, the apatite layer forms onto the composite surface and this phenomenon is confirmed by SEM of $\mathrm{BC} 1, \mathrm{BC} 2, \mathrm{BC} 3, \mathrm{BC} 4$ composites post-immersion as shown in Figure $3 \mathrm{~b}, \mathrm{BC} 1$

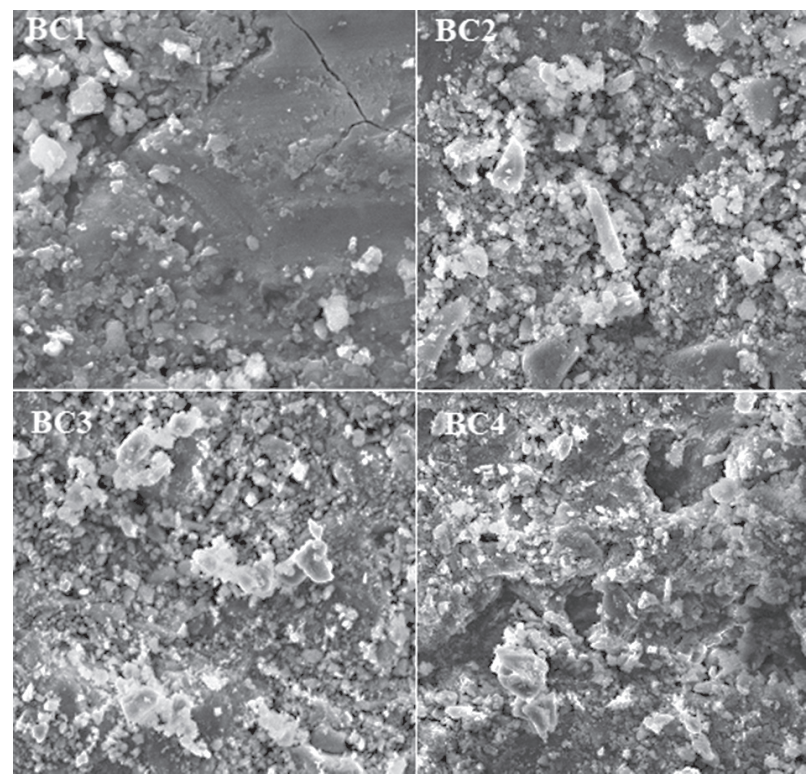

a) before soaked in SBF solution

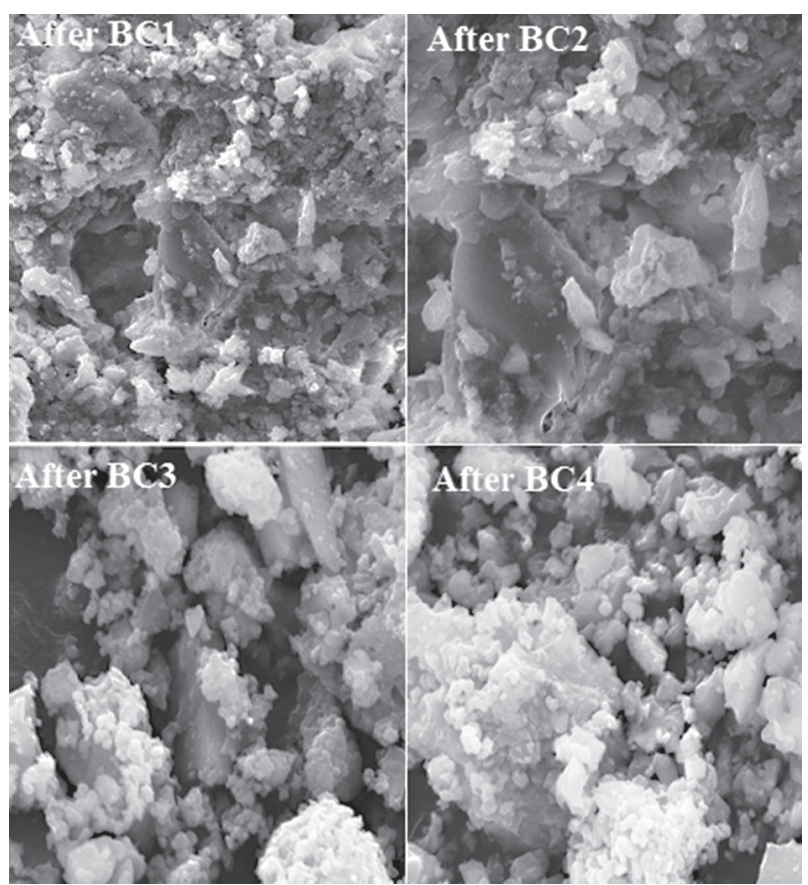

b) after soaked in SBF solution

Figure 3. SEM micrographs of biocomposite samples BC1, BC2, BC3, BC4 before (a) and after (b) soaked in SBF solution for 21 days. biocomposites, shows that composite has many particles on its surface proving slight formation of apatite layer because it contains high content of silica characterizing melted and dense structure that reduce nucleation of apatite layer as compared to other composites. The formation of silanol groups on material's surface which are essential for nucleation sites for HA formation is due to the simultaneous dissolution of silicates [30]. Once the apatite nuclei formed, they can grow spontaneously by uptaking calcium phosphate ions from the surrounding fluid [31]. For BC2, BC3 and BC4 composites, SEM at the high magnification indicates the presence of rich spherical shapes build upon each other to form a bonelike apatite layer for both composites especially BC4 composites.

\section{$\mathrm{pH}$ behavior in $\mathrm{SBF}$}

After soaking of biocomposite for various time periods, the variation in $\mathrm{pH}$ values of simulated body fluid (SBF) is shown in Figure 4. It was observed that the $\mathrm{pH}$ of all samples shows the similar trend of behavior [32]. On 1 day of immersion, maximum $\mathrm{pH}$ values were recorded. Ion exchange method was used to explain, the change in $\mathrm{pH}$ of SBF solution on the glass surface. Cations such as $\mathrm{Na}^{+}$or $\mathrm{Ca}^{2+}$ near the glass surface releases into the solution in exchange of $\mathrm{H}^{+}$or $\mathrm{H}_{3} \mathrm{O}^{+}$ions from the solutions which results in $\mathrm{pH}$ increase, After certain point the precipitation of calcium phosphates and carbonates results in decrease in $\mathrm{pH}$. The update of carbonate and phosphate ions shifts the equilibriums towards the products side, and causes decrease in the $\mathrm{pH}$ [33]. There is addition of HA in base bioactive glass (45S5) to make biocomposites. After immersion of biocomposite in SBF for various time periods, chain of reactions occurs in the solution which favours the formation of hydroxyapatite layer on the surface of the samples [34-35].

$$
\begin{aligned}
& \mathrm{HCO}_{3}{ }^{3-} \rightarrow \mathrm{CO}_{3}{ }^{2-}+\mathrm{H}^{+} \text {and } \\
& \mathrm{HPO}_{4}{ }^{2-} \rightarrow \mathrm{PO}_{4}{ }^{3-}+\mathrm{H}^{+}
\end{aligned}
$$

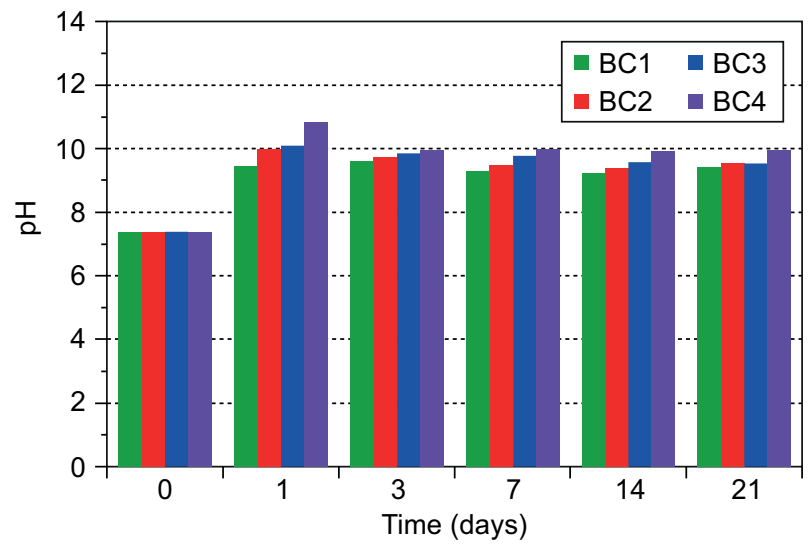

Figure 4. $\mathrm{pH}$ of different biocomposite (BC1, BC2, BC3, BC4).

Ceramics - Silikáty 61 (4) 378-384 (2017) 
Prasad S., Vyas V. K., Ershad Md., Pyare R.

Table 3. Density $(\rho)$, longitudinal velocity $\left(V_{L}\right)$ and transverse velocity $\left(V_{T}\right)$, Young's modulus $(E)$, shear modulus $(G)$, bulk modulus $(K)$ and Poisson's ratio $(v)$ of biocomposites.

\begin{tabular}{lccccccc}
\hline Sample & $\begin{array}{c}\text { Density } \rho \\
\left(\mathrm{g} \cdot \mathrm{cm}^{-3}\right)\end{array}$ & $\begin{array}{c}V_{L} \\
\left(\mathrm{~m} \cdot \mathrm{s}^{-1}\right)\end{array}$ & $\begin{array}{c}V_{T} \\
\left(\mathrm{~m} \cdot \mathrm{s}^{-1}\right)\end{array}$ & $\begin{array}{c}\text { Young's modulus } \\
E(\mathrm{GPa})\end{array}$ & $\begin{array}{c}\text { Shear modulus } \\
G(\mathrm{GPa})\end{array}$ & $\begin{array}{c}\text { Bulk modulus } \\
K(\mathrm{GPa})\end{array}$ & $\begin{array}{c}\text { Poisson's ratio } \\
(\mathrm{v})\end{array}$ \\
\hline BC1 & 2.45 & 4412 & 2315 & 34 & 13 & 29 & 0.3103 \\
BC2 & 2.44 & 4552 & 2516 & 39 & 15 & 30 & 0.2801 \\
BC3 & 2.42 & 4782 & 2729 & 44 & 18 & 32 & 0.2721 \\
BC4 & 2.40 & 4932 & 2911 & 50 & 20 & 34 & 0.2326 \\
\hline
\end{tabular}

\section{Mechanical Properties}

Compressive strength and elastic modulus of biocomposite during in vitro test

The compressive strength and elastic modulus of the $\mathrm{BC} 3$ biocomposite after immersion in SBF in vitro are shown in Figure 5 as a function of immersion time. The strength and modulus decreased rapidly during first 3 days but later on its decrease becomes slow. This trend was independent of in-vitro treatment. During invitro test the strength decreases from fabricated value of $82 \pm 5 \mathrm{MPa}$ to $70 \pm 5 \mathrm{MPa}$ after 7 days treatment in SBF. After 21 days, the strength of the biocomposite immersed in SBF was $72 \pm 8 \mathrm{MPa}$. The elastic modulus decreased from fabricated value of $42 \pm 5 \mathrm{GPa}$ to $32 \pm 5 \mathrm{GPa}$ after 7 days in SBF in vitro test. After 21 days, the strength of the biocomposite immersed in SBF was $36 \pm 8 \mathrm{GPa}$.
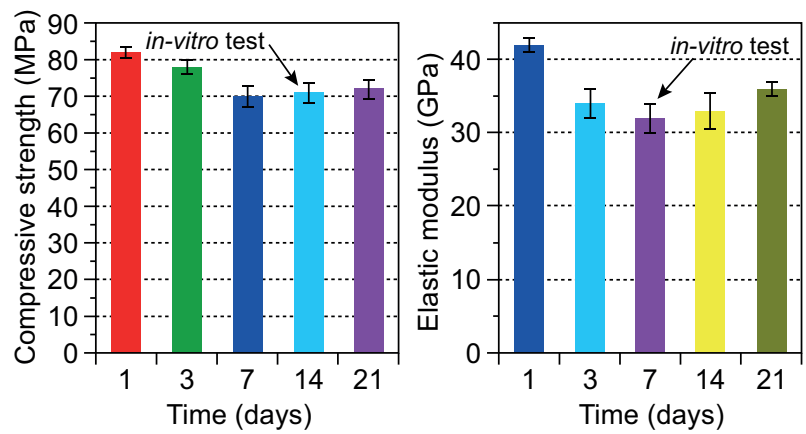

Figure 5. Compressive strength and Elastic modulus as a function of time for $\mathrm{BC} 3$ biocomposites after immersion in simulated body fluid (SBF) in vitro test.

\section{Elastic properties of biocomposites}

In Figure 6 shows compressive strength and hardness value. Compressive strength and hardness values shows between (30 MPa to $99 \mathrm{MPa})$ and $(105 \mathrm{MPa}$ to $374 \mathrm{MPa})$. The results indicate that with an initial addition of HA, the elastic modulus shows an anomalous behaviour. It increases with further addition of HA content as shown in Figure 7. In BC1 and BC4 biocomposite, the measured young's and shear moduli ranges from 34 to $50 \mathrm{GPa}$ and 13 to $20 \mathrm{GPa}$ respectively. Similarly, the poisson's ratio and bulk moduli ranges from 0.31 to 0.23 and 29 to $34 \mathrm{GPa}$ Figure 8 for $\mathrm{BC} 1$ and $\mathrm{BC} 4$ biocomposites. The elastic modulus increases with increase in the rigidity of biocomposite [36].

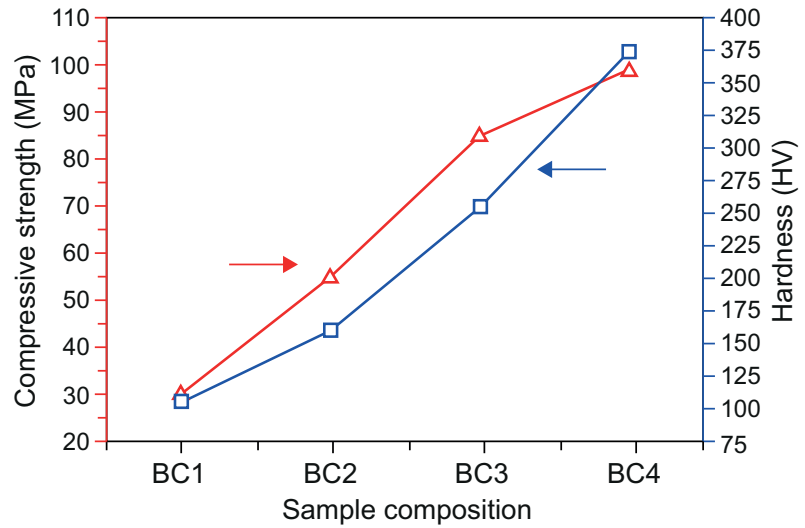

Figure 6. Compressive strength and hardness of biocomposites (BC1, BC2, BC3, BC4).

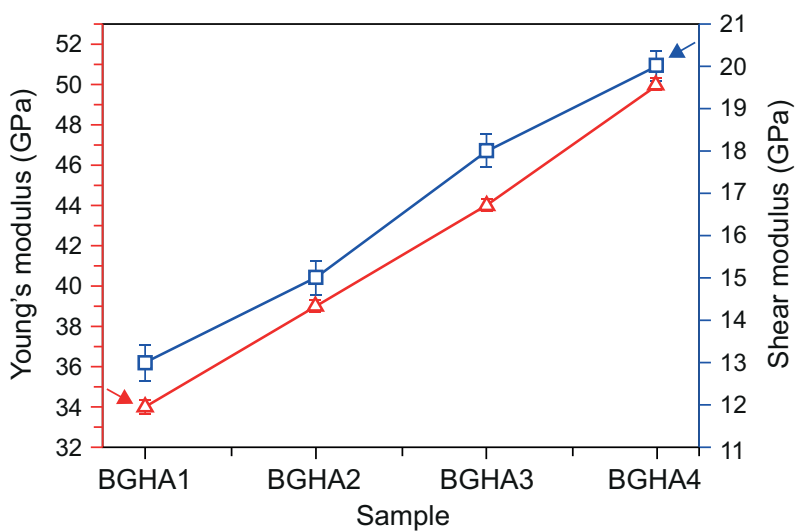

Figure 7. Young's modulus and shear modulus of biocomposites (BC1, BC2, BC3, BC4).

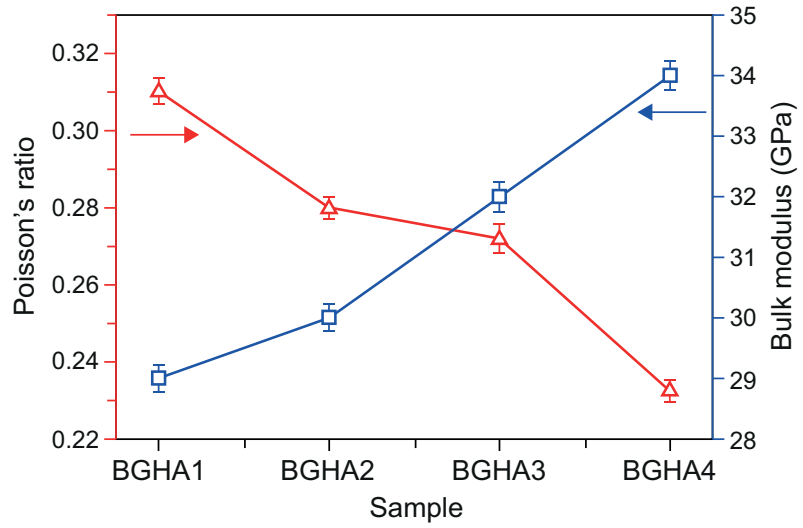

Figure 8. Bulk modulus and poisson's ratio of biocomposites (BC1, BC2, BC3, BC4). 


\section{CONCLUSION}

Sintering process is used to prepare biocomposites with addition of HA in Bioactive glass (45S5). The thermal treatment of silicate based glasses results in the release of stresses from the glass. There is possible formation of crystalline phases along with the residual glassy phases. The increase of HA content in bioglass composites result in increase of density, compressive strength, Youngs, shear and bulk modulus while the poisson's ratio remains nearly constant. Mechanical properties of the samples can be measured without any effect to the biocomposites. Mechanical properties shows good strength of biocomposites. Since the biomaterials are very expensive to prepare.

\section{Acknowledgment}

The authors gratefully acknowledge the Department of Ceramic Engineering, IIT (BHU) and Central Instrument Fascility, IIT (BHU) Varanasi, India for providing necessary facilities for the present research work. The present work was supported by Grant from Rajiv Gandhi National Fellowship, University Grant Commission, New Delhi, India.

\section{REFERENCES:}

1. Hench L.L., Andersson O. (1993). Bioactive glasses, in: Hench L.L., Wilson J. (ed.): An Introduction to Bioceramics. World Scientific. pp. 41-62.

2. Stan G. E., Popa A. C., Galca A. C., Aldica G., Ferreira, J. M. F. (2013): Strong bonding between sputtered bioglassceramic films and Ti-substrate implants induced by atomic inter-diffusion post-deposition heat-treatments. Applied Surface Science, 280, 530-538. doi: 10.1016/j.apsusc. 2013.05.022

3. Hench L.L., Splinter R.J., Allen W.C., Greenlee T.K. (1971): Bonding mechanisms at the interface of ceramic prosthetic materials. Journal of Biomedical Materials Research Part A, 5(6), 117-141. doi: 10.1002/jbm.820050611

4. Gomez-Vega JM, Saiz E, Tomsia AP. (1999): Glassbased coatings for titanium implant alloys. Journal of Biomedical Materials Research Part A, 46(4), 549-559. doi: 10.1002/(SICI)1097-4636(19990915)46:4<549::AIDJBM13>3.0.CO;2-M

5. Aldini NN, Fini M, Giavaresi G, Torricelli P, Martini L, Giardino R. (2002): Improvement in zirconia osseointegration by means of a biological glass coating: an in vitro and in vivo investigation. Journal of Biomedical Materials Research Part A, 61,282-291. doi: 10.1002/jbm.10162

6. Cannillo V, Sola A. (2010): Different approaches to produce coatings with bioactive glasses: enamelling vs plasma spraying. Journal of the European Ceramic Society, 30(10), 2031-2039. doi: 10.1016/j.jeurceramsoc.2010.04.021

7. Rahaman MN, Day DE, Bal BS, Fu Q, Jung SB (2011): Bonewald LF, et al. Bioactive glass in tissue engineering. Acta Biomaterialia, 7(6), 2355-2373. doi: 10.1016/j.actbio. 2011.03.016
8. Nandi SK, Kundu B, Ghosh SK. (2009): Cefuroximeimpregnated calcium phosphates as an implantable delivery system in experimental osteomyelitis. Ceramic International, 35, 1367-1376. doi: 10.1016/j.ceramint.2008.07.022

9. Li Z., Khun N.W., Tang X.Z., Liu E., Khor K.A. (2016): Mechanical, tribological and biological properties of novel 45S5 bioglass composites reinforced with in situ reduced graphene oxide. Journal of the Mechanical Behavior of Biomedical Materials, 65, 77-89. doi: 10.1016/j.jmbbm. 2016.08.007

10. Westhauser F., Weis C., Prokscha M., Bittrich L.A., Li W., Xiao K., Kneser U., Kauczor H.U., Schmidmaier G., Boccaccini A.R., Moghaddam A. (2016): Three-dimensional polymer coated 45S5-type bioactive glass scaffolds seeded with human mesenchymal stemcells show bone formation in vivo. Journal of Materials Science: Materials in Medicine, 27(7), 1-7. doi: 10.1007/s10856-016-5732-3

11. Anderegg CR, Alexander DC, Freidman MA. (1999): Bioactive glass particulate in the treatment of molar furcation invasions. Journal of Periodontology, 70(4), 384-387. doi: 10.1902/jop.1999.70.4.384

12. Kim CK, Kim HY, Chai JK. (1998): Effect of a calcium sulfate implant with calcium sulfate barrier on periodontal healing in 3 wall infrabony defects in dogs. Journal of Periodontology, 69, 982-990. doi: 10.1902/jop.1998. 69.9.982

13. Shankhwar N., Kothiyal G.P., Srinivasan A. (2015): Influence of phosphate precursor on the structure, crystallization behaviour and bioactivity of sol-gel derived 45S5 bioglass. RSC Advances, 5(122), 100762-100768. doi: 10.1039/C5RA19184J

14. Tanner K.E. (2010): Bioactive composites for bone tissue engineering. Proceedings of the Institution of Mechanical Engineers, Part H: Journal of Engineering in Medicine, 224(12), 1359-1372. doi: 10.1243/09544119JEIM823

15. Hench L.L. (2006): The story of bioglass. Journal of Materials Science: Materials in Medicine, 17, 967-978. doi: 10.1007/s10856-006-0432-z

16. Jones J. R. (2013): Review of bioactive glass: from Hench to hybrids. Acta Biomaterialia, 9, 4457-4486. doi: 10.1016/ j.actbio.2012.08.023

17. Hench L.L., Polak J.M. (2002): Third-generation biomedical materials. Science, 295(5557), 1014-1017. doi: 10.1126/science. 1067404

18. Cao W., Hench L.L.(1996): Bioactive materials. Ceramic International, 35, 22, 493-507. doi: 10.1016/0272-8842 (95)00126-3

19. Ohtsuki C., Iida H., Nakamura S., Osaka A. (1997): Bioactivity of titanium treated with hydrogen peroxide solutions containing metal chlorides. Journal of Biomedical Materials Research Part A, 35(1), 39-47. doi: 10.1002/(SICI)10974636(199704)35:1<39::AID-JBM5>3.0.CO;2-N

20. Kokubo K., Ito S., Huang Z. T., Hayashi T., Sakka S., Kitsugi T., Yamamuro T. (1990): Solutions able to reproduce in vivo surface-structure changes in bioactive glass-ceramics A-W. Journal of Biomedical Materials Research Part A, 24(6), 721-734. doi: 10.1002/jbm. 820240607

21. Azevedo M. M., Jell G., Donnell M. D. O', Law R. V., Hill R. G. and Stevens M. M. (2010): Synthesis and characterization of hypoxiamimicking bioactive glasses for skeletal regeneration. Journal of Materials Chemistry, 20(40), 8854-8864. doi: 10.1039/C0JM01111H 
22. Salinas A.J., Martin A.I., Vallet-Regi M.(2002): Bioactivity of three $\mathrm{CaO}-\mathrm{P}_{2} \mathrm{O}_{5}-\mathrm{SiO}_{2}$ sol-gel glasses, Journal of Biomedical Materials Research Part A, 61(4), 524-532. doi: 10.1002/jbm.10229

23. Aza P.N. De, Fernandez-Pradas J.M., Serra P. (2004): Invitro bioactivity of laser ablation Pseudo wollastonite coating. Biomaterials, 25, 1983-1990. doi: 10.1016/j.biomaterials.2003.08.036

24. Sarmento C., Luklinska Z.B., Brown L., Anseau M., De Aza P.N., De Aza S., Hughes F.J., McKay I.J. (2004): In vitro behavior of osteoblastic cells cultured in the presence of pseudo wollastonite ceramic. Journal of Biomedical Materials Research Part A, 69(2), 351-358. doi: 10.1002/ jbm.a.30012

25. De Aza P.N., Luklinska Z.B., Martinez, Anseau M.R., Guitian F., De Aza S. (2000): Morphological and structural study of pseudo wollastonite implants in bone. Journal of Microscopy(UK), 197(1), 60-67. doi: 10.1046/j.13652818.2000.00647.x

26. De Aza P.N., Luklinska Z.B., Anseau M.R., Guitian F., De Aza S. (1999) : Bioactivity of Pseudo wollastonite in human saliva, Journal of Dentistry, 27(2), 107-113. doi: 10.1016/S0300-5712(98)00029-3

27. Sebdani M.M., Fathi M.H. (2012): Preparation and characterization of hydroxyapatite-forsterite-bioactive glass nanocomposite coatings for biomedical applications. Ceramic International, 38, 1325-1330. doi: 10.1016/j.ceramint. 2011.09.008

28. Hench L.L. (2001). The discovery of bioactive glasses, in: Science Faith and Ethics. $1^{\text {st }}$ ed. Imperial College Press.

29. Kokubo T., Kim H., M. Kawashita (2003): Novel bioactive materials with different mechanical properties. Biomaterials, 24(13), 2161-2175. doi: 10.1016/S0142-9612 (03)00044-9
30. Karlsson K.H. (2004): Bioactivity of glass and bioactive glasses for bone repair. Glass Technology, 45(4), 157-161.

31. Ebisawa Y., Kokubo T., Ohura K., Yamamuro T. J. (1993): Bioactivity of $\mathrm{CaO} \cdot \mathrm{SiO}_{2}$-based glasses: in vitro evaluation. Journal of Materials Science: Materials in Medicine, 1(4), 239-244. doi: 10.1007/BF00701083

32. Cerruti M., Greenspan D., Powers K. (2005): Effect of $\mathrm{pH}$ and ionic strength on the reactivity of Bioglass ${ }^{\circledR} 45 \mathrm{~S} 5$. Biomaterials, 26(14), 1665-1674. doi: 10.1016/j.biomaterials.2004.07.009

33. Brauer Delia S., Karpukhina Natalia, O'Donnell Matthew D., Law Robert V., Hill Robert G. (2010): Fluoridecontaining bioactive glasses: Effect of glass design and structure on degradation, $\mathrm{pH}$ and apatite formation in simulated body fluid. Acta Biomaterialia, 6, 3275-3282. doi: 10.1016/j.actbio.2010.01.043

34. Mastelaro V.R., Zanotto E.D., Lequeux N., Cortes R (2000): Relationship between short-range order and ease of nucleation in $\mathrm{Na}_{2} \mathrm{Ca}_{2} \mathrm{Si}_{3} \mathrm{O}_{9}, \mathrm{CaSiO}_{3}$ and $\mathrm{PbSiO}_{3}$ glasses. Journal of Non-Crystalline Solids, 262(1), 191-199. doi: 10.1016/S0022-3093(99)00685-7

35. Ducheyne P., Qiu Q. (1999): Bioactive ceramics: the effect of surface reactivity on bone formation and bone cell function. Biomaterials, 20(23), 2287-2303. doi: 10.1016/ S0142-9612(99)00181-7

36. Gayathri Devi A.V., Rajendran V., Jeyasubramanian K., Suresh Kumar N. and Hameed S.A.M. Abdel.(2006): Ultrasonic Investigation on Nanocrystalline Barium Borate (BBO) Glass Ceramics, Synthesis and Reactivity in Inorganic, Metal-Organic and Nano-Metal Chemistry, 36, 215-219. 